\title{
Successful Live Births after Laparoscopic Management of Heterotypic Pregnancies in Assisted Reproductive Technology Cycles: A Tertiary Fertility Center Experience
}

\author{
${ }^{1}$ Aradhana Kalra, ${ }^{2}$ Akshay K Nadkarni, ${ }^{3}$ Purnima K Nadkarni, ${ }^{4}$ Pooja Singh
}

\begin{abstract}
Background: To review and analyze the incidence of heterotypic pregnancies after intracytoplasmic sperm injection (ICSI) and embryo transfer and to report pregnancy outcome after successful management of heterotypic pregnancies.
\end{abstract}

Setting: Nadkarni's 21st Century Hospitals and Test Tube Baby Center, Surat, Gujarat, India.

Design: Retrospective study.

Materials and methods: Retrospective data were taken from hospital records from January 2013 to December 2015. A total of 2,771 patients underwent in vitro fertilization IVF/ICSI, out of which 1,455 patients were pregnant $(52.5 \%)$. Out of the pregnant patients, the incidence of ectopic (EP) and heterotypic pregnancies was calculated. The etiological factors, management of heterotypic pregnancies, and their pregnancy outcome were reported.

Conclusion: Out of the 1,455 pregnant patients, there were 29 EPs (EPs: $1.99 \%$ ) and 5 were heterotypic (0.34\%). Laparoscopic intervention was done for all five of them and successful pregnancy outcome was reported in terms of live birth.

Clinical significance: Heterotypic pregnancy is rare and poses a diagnostic dilemma in assisted reproductive technology (ART) cycles. Serial beta-human chorionic gonadotropin (hCG) measurement is not reliable and ultrasonography may not confirm due to the presence of ovarian hyperstimulation syndrome (OHSS) or multiple cysts. Early diagnosis is ideal and good perinatal outcome can be achieved by prompt and excellent laparoscopic management of the heterotypic pregnancies.

Keywords: Cesarean section, Heterotypic, Laparoscopic salpingectomy, Tubal disease.

How to cite this article: Kalra A, Nadkarni AK, Nadkarni PK, Singh P. Successful Live Births after Laparoscopic Management of Heterotypic Pregnancies in Assisted Reproductive Technology Cycles: A Tertiary Fertility Center Experience. Int J Infertil Fetal Med 2017;8(3):125-127.

\footnotetext{
1,2,4Consultant, ${ }^{3}$ Director

${ }^{1}$ Department of Reproductive Medicine, Milann-The Fertility Center, New Delhi, India

2Department of Laparoscopic Surgery and Oncology, Nadkarni's 21st Century Hospitals and Test Tube Baby Centre, Vapi Gujarat, India

3,4 Department of Reproductive Medicine, Nadkarni's 21st Century Hospitals and Test Tube Baby Centre, Surat, Gujarat, India
}

Corresponding Author: Aradhana Kalra, Consultant, Department of Reproductive Medicine, Milann-The Fertility Center, New Delhi India, Phone: +919971817954, e-mail: draradhanakalra@ gmail.com
Source of support: Nil

Conflict of interest: None

Date of received: 29/06/2017

Date of acceptance: 28/08/2017

Date of publication: November 2017

\section{BACKGROUND}

Ectopic pregnancy refers to the implantation of a viable ovum outside the uterine corpus. Heterotypic pregnancy (HP) is the presence of simultaneous gestations at two or more implantation sites. It was first reported in the year 1708 as an autopsy finding. ${ }^{1}$ It is most often manifested as concomitant intrauterine pregnancy (IUP) and EP. ${ }^{2}$ Although EP is not uncommon in women of reproductive age, $\mathrm{HP}$ is rare in the general population, with an occurrence range estimated between 1:7,963 and 1:30,000. ${ }^{3,4}$ The increased incidence of pelvic inflammatory disease (PID), the common use of ovarian stimulation, and the advent of ARTs have contributed to the increasing incidence of both multiple gestations and HP during the past years. The rate of HP after IVF has been reported to be as high as $1 \%,^{3-6}$ although true incidence is not exactly known. These difficult pregnancies are diagnostic and therapeutic challenges to practitioners of ART. ${ }^{7}$ Serial hCG level measurements are not useful aids due to the concomitant IUP. Furthermore, the frequent presence of an OHSS, after ART masking the EP of HP cases, impairs the ability to reach a definitive diagnosis before surgery.

We report the incidence of EP and heterotypic pregnancies after ART over 3 years at our center and successful pregnancy outcome after timely management of heterotypic pregnancies.

\section{CASE REPORT}

The study was carried out in a tertiary center for assisted reproduction from January 2013 to December 2015. We performed a retrospective notes and data review. A total of 2,771 patients underwent IVF/ICSI during this period. Out of them, 1,455 patients were pregnant $(52.5 \%)$. There were 29 cases of EP $(1.99 \%)$ and 5 were heterotypic $(0.34 \%)$. The mean age of the patients with heterotypic pregnancy was 33 years. Tubal factor was present in three patients $(60 \%)$ 
Table 1: Characteristics of the patients

\begin{tabular}{|c|c|c|c|c|c|}
\hline Patient & Age & Etiology & $\begin{array}{l}\text { Embryo } \\
\text { transfer } \\
\text { D2/3/5/ } \\
\text { Sequential }\end{array}$ & $\begin{array}{l}\text { No. of } \\
\text { embryos }\end{array}$ & $\begin{array}{l}\text { Distance } \\
\text { from the } \\
\text { fundus } \\
\text { (cm) }\end{array}$ \\
\hline \multirow[t]{2}{*}{1} & 40 & $\begin{array}{l}\text { Low ovarian } \\
\text { reserve }+\end{array}$ & Sequential & 4 & D2: 1.4 \\
\hline & & Tubal factor & D2 and D5 & & D5: 1.5 \\
\hline 2 & 31 & $\begin{array}{l}\text { Male factor + } \\
\text { RIF }\end{array}$ & $\begin{array}{l}\text { Sequential } \\
\text { D2 and D5 }\end{array}$ & 3 & $\begin{array}{l}\text { D2: } 1.35 \\
\text { D5: } 1.5\end{array}$ \\
\hline 3 & 33 & Tubal factor & $\begin{array}{l}\text { Sequential } \\
\text { D2 and D5 }\end{array}$ & 3 & $\begin{array}{l}\text { D2: } 1.24 \\
\text { D5: } 1.52\end{array}$ \\
\hline 4 & 33 & Tubal factor & D3 & 3 & 1.54 \\
\hline 5 & 28 & Unexplained & $\begin{array}{l}\text { Sequential } \\
\text { D2 and D5 }\end{array}$ & 3 & $\begin{array}{l}\text { D2: } 1.42 \\
\text { D3: } 1.53\end{array}$ \\
\hline
\end{tabular}

RIF: Recurrent implantation failure

(isolated tubal factor in two and as a combined factor in one patient, Table 1). Sequential transfer (day 2 and then day 5 blastocyst transfer) was done in four patients while in one patient, 3 days three embryos were transferred (grade I and II). The mean distance from the fundus was $1.44 \mathrm{~cm}$ (range $1.24-1.54 \mathrm{~cm}$ ).

The mean gestational age at the time of presentation was 8 weeks. We do a serum beta-hCG on day 16 after embryo transfer and ultrasonography is done at 6 weeks and repeated in the second visit at 8 weeks. Two patients presented with ruptured EP at 9 and 8 weeks respectively (Table 2). One of them had a cornual pregnancy. Both the patients were seen in emergency and immediately managed by laparoscopic intervention. Patients were transfused blood intra- and postoperatively. One patient was diagnosed at the time of routine scan at 8 weeks and the other two were admitted for acute gastroenteritis and vaginal bleeding respectively, and were subsequently diagnosed on ultrasonography. No patient had a previous history of EP. About $20 \%$ (6 out of 29) of the patients who had EP had a prior history of EP. Laparoscopic cornuotomy in one and laparoscopic salpingectomy was done in other four patients. Luteal support with ethinyl estradiol and micronized progesterone was continued up to 13 weeks and further only micronized progesterone was given up to 16 weeks.

Patients were monitored regularly during their antenatal period. Our first patient had an oocyte donation, ICSI cycle. She developed preeclampsia at 28 weeks and underwent cesarean at 34 weeks delivering a healthy single live child. Among the other two patients with singleton pregnancies, one underwent cesarean at 35 weeks for preterm premature rupture of membranes and fetal distress and the other elective cesarean at 37 weeks. Two out of the five pregnancies had twins and underwent elective cesarean at 36 weeks.

\section{DISCUSSION}

The dictum "think ectopic" signifies the difficulty in achieving the correct diagnosis of EP. ${ }^{8}$ However, when an IUP is diagnosed the dictum does not have not an immediate application. The reason being (1) occurrence of a HP is rare, $0.08 \%$ in natural conception cycles, up to $1 \%$ with ART; (2) serial beta-hCG levels are not of much significance in the diagnosis as subnormal hormone production by an EP may be masked by the higher placental production from the IUP; (3) presence of cysts or OHSS masks the EP. Signs and symptoms, such as abdominal pain, adnexal mass, and peritoneal irritation are nonspecific and may be confused with other normal or abnormal pregnancy manifestations. HP is difficult to ascertain as pain and bleeding might be attributed to a threatened abortion. ${ }^{9}$ Literature review from 1994 to 2004 also showed that out of 80 cases, 21 were diagnosed by ultrasound (USG) and 59 at laparoscopy or laparotomy. ${ }^{1}$ The risk factors like tubal disease, PID, and previous pelvic surgery may not always be present though ART itself predisposes to its increased chance.

The standard treatment for heterotypic pregnancy is surgery by laparoscopy or laparotomy depending upon the condition of the patient. The main aim of the surgery should be the preservation of the IUP with minimal manipulation of the uterus. With the current advances in

Table 2: Patient's presentation and outcome

\begin{tabular}{|c|c|c|c|c|c|c|c|}
\hline Patient & $\begin{array}{l}\text { Gestational age } \\
\text { at presentation } \\
\text { (weeks) }\end{array}$ & Presenting complaint(s) & $\begin{array}{l}\text { Ruptured/ } \\
\text { unruptured }\end{array}$ & $\begin{array}{l}\text { Site of } \\
\text { pregnancy }\end{array}$ & $\begin{array}{l}\text { 1st beta- } \\
\text { hCG D16 } \\
\text { posttransfer }\end{array}$ & $\begin{array}{l}\text { 2nd beta- } \\
\text { hCG D20 } \\
\text { posttransfer }\end{array}$ & $\begin{array}{l}\text { Outcome } \\
\text { Twin/single }\end{array}$ \\
\hline 1 & 9 & $\begin{array}{l}\text { Hypotension, intraperitoneal } \\
\text { hemorrhage }\end{array}$ & Ruptured & Cornual & 1,292 & & $\begin{array}{l}\text { Single LSCS } \\
\text { at } 34 \mathrm{wks}\end{array}$ \\
\hline 2 & 8 & $\begin{array}{l}\text { Hypotension, intraperitoneal } \\
\text { hemorrhage }\end{array}$ & Ruptured & Tubal & 1,121 & & $\begin{array}{l}\text { Twin LSCS } \\
\text { at } 36 \text { wks }\end{array}$ \\
\hline 3 & 8 & No complaints USG diagnosis & Unruptured & Tubal & 923 & & $\begin{array}{l}\text { Single LSCS } \\
\text { at } 37 \mathrm{wks}\end{array}$ \\
\hline 4 & 7 & $\begin{array}{l}\text { Pain abdomen, vaginal } \\
\text { bleeding }\end{array}$ & Unruptured & Tubal & 523 & 4,232 & $\begin{array}{l}\text { Single LSCS } \\
\text { at } 35 \mathrm{wks}\end{array}$ \\
\hline 5 & 8 & $\begin{array}{l}\text { Acute gastroenteritis USG: } \\
\text { heterotypic live gestation }\end{array}$ & Unruptured & Tubal & 913 & & $\begin{array}{l}\text { Twin LSCS } \\
\text { at } 36 \text { wks }\end{array}$ \\
\hline
\end{tabular}

LSCS: Lower segment cesarean section 
laparoscopy, it seems to be the preferred method even for cornual EP. Experienced laparoscopic operator is crucial in such cases in order to have the ability to deal with possible high risk of heavy bleeding when treatment of cornual EPs is accomplished laparoscopically.

The prognosis of IUP is favorable in 60 to $70 \%$ of cases. Tal et $\mathrm{al}^{5}$ proceeded to full term in $66 \%$, while in the study by Barrenetxea et al, ${ }^{10} 69 \%$ proceeded to full term. The improvement in IUP survival rate is probably due to better diagnostic and treatment developments and close followup of patients after ART techniques. In our study, all the patients had a successful pregnancy outcome in terms of live birth and three out of five were diagnosed because of the close surveillance in these patients who undergo ART. No differences in IUP outcome were observed between patients with or without hemoperitoneum.

\section{CONCLUSION}

Detection of an IUP does not exclude the possibility of the simultaneous existence of an EP. Hence, in all patients of reproductive age and especially in those who have undergone ART, even in the presence of an IUP, a complete review of the whole pelvis including adnexa should be done at the time of USG to rule out the presence of a HP. Laparoscopic management of heterotypic pregnancies assures a good outcome for the IUP.

\section{CLINICAL SIGNIFICANCE}

Heterotypic pregnancy is like a black cat in the dark, easily missed if not actively looked for. With the rising incidence of medicolegal cases against doctors, it is imperative to look for heterotypic pregnancy in all cases of ART despite the condition being rare. This is to ensure their timely detection and laparoscopic management so as to ensure good prognosis of the intrauterine pregnancy.

\section{REFERENCES}

1. Bright DA, Craupp FB. Heterotopic pregnancy: a re-evaluation. J Am Board Fam Pract 1990 Apr-Jun;3(2):125-128.

2. Louis-Sylvestre C, Morice P, Chapron C, Dubuisson JB. The role of laparoscopy in the diagnosis and management of heterotopic pregnancies. Hum Reprod 1997 May;12(5):1100-1102.

3. Chin HY, Chen FP, Wang CJ, Shui LT, Liu YH, Soong YK. Heterotopic pregnancy after in-vitro fertilization-embryo transfer. Int J Gynecol Obstet 2004 Sep;86(3):411-416.

4. Reece EA, Petrie RH, Sirmans MF, Finster M, Todd WD. Combined intrauterine and extrauterine gestations: a review. Am J Obstet Gynecol 1983 Jun;146(3):323-330.

5. Tal J, Haddad S, Gordon N, Timor-Tritsch I. Heterotopic pregnancy after ovulation induction and assisted reproductive technologies: a literature review from 1971 to 1993. Fertil Steril 1996 Jul;66(1):1-12.

6. Inion I, Gerris J, Joostens M, De Vree B, Kockx M, Verdonk P. An unexpected triplet heterotopic pregnancy after replacement of two embryos. Hum Reprod 1998 Jul;13(7):1999-2001.

7. Pisarka MD, Casson PR, Moise KJ Jr, DiMaio DJ, Buster JE, Carson SA. Heterotopic abdominal pregnancy treated at laparoscopy. Fertil Steril 1998 Jul;70(1):159-160.

8. Chan LYS, Fok WY, Yuen PM. Pitfalls in diagnosis of interstitial pregnancy. Acta Obstet Gynecol Scand 2003;82:867-870.

9. Cheng PJ, Chueh HY, Qiu JT. Heterotopic pregnancy in a natural conception cycle presenting as hematometra. Obstet Gynecol 2004 Nov;104(5 pt 2):1195-1198.

10. Barrenetxea G, Barinaga-Rementeria L, de Larruzea AL, Agirregoikoa JA, Mandiola M, Carbonero K. Heterotopic pregnancy: two cases and a comparative review. Fertil Steril 2007 Mar;87:417 e9-e15. 